\title{
BUSINESS OBLIGATIONS ON HUMAN RIGHTS IN THE INFORMATION SOCIETY
}

The article discusses the human rights business obligations in the information society. Obligatory and voluntary business obligations, direct and indirect obligations are considered. The global and national strategies for regulating companies and developing appropriate standards are identified. Features of responsibility of transnational corporations, IT companies, impact on the latest and recognized human rights are investigated.

Keywords: human rights, human rights concept, business obligations, information society, transnational corporations.

Размєтасва Юлія. Зобов'язання бізнесу щодо прав людини в інформаційному суспільстві

Статтю присвячено питанням зобов'язань бізнесу у сфері прав людини в інформаційному суспільстві. Розглядаються обов'язкові та добровільні зобов'язання бізнесу, покладання прямих та непрямих обов'язків. Виокремлюються глобальні та національні стратегії регулювання діяльності компаній та вироблення відповідних стандартів. Досліджуються особливості відповідальності транснаиіональних корпораиій, компаній, що прачюють у сфері IT, вплив на новітні й визнані права людини.

Ключові слова: права людини, концепція прав людини, зобов'язання бізнесу, інформаційне суспільство, транснаціональні корпорації.

Relevance of the research topic. The influence of business as a non-state player of public relations on the implementation and protection of human rights has increased significantly in recent years. The role of IT companies and transnational corporations is particularly prominent in today's information society. At the same time, there are shifts in the concept of human rights that are largely related to the development of digital technologies and the information economy. The complexity of regulatory and jurisdictional issues in a globalized world, the increasing 
interdependence of states and organizations, and the particularities of cyberspace development add new dimensions to these issues.

All of the above encourages us to discuss and implement the standards of activity and responsibility of a business, its binding and voluntary human rights obligations.

Formulation of the problem. Although the human rights obligations of the business are enshrined in a number of international acts and implemented at the level of some states in a number of countries, there are strong reasons to believe that this is not enough to ensure an adequate level the realization and protection of the human rights in the information society.

First, there is no universal model of human rights business obligations. This applies to both the regulatory framework and the theoretical framework. The best results can be found in documents such as the Guiding Principles for Business and Human Rights: Implementing the United Nations «Protect, Respect and Remedy» Framework, UN Global Compact, OECD Guidelines for Multinational Enterprises, OECD Declaration on International Investment and Multinational Enterprises, Decisions and Recommendations. The discussions about the nature and scope of such obligations, their maintenance, support and consequences of non-compliance are ongoing within the UN and intergovernmental groups, in civil society and academic community.

Second, it is difficult to predict what impact business will have on human rights in the digital age, as geopolitical and geo-economic shifts are occurring at an extraordinary rate. On the one hand, vulnerability in the protection of data of a powerful corporation can have consequences such as the unexpected results of elections and referenda in some states, massive violations of the right to privacy, distortions in the realization of the right to information. On the other hand, the well-thought-out advertising campaign of a powerful corporation, focused on individual rights, would be able to benefit not only the business structure but also society, promote social change and act as an educational tool. UN General Assembly in its resolution of 19 December 2016 «Globalization and its impact on the full enjoyment of all human rights» recognizes that «the responsible operations of transnational corporations and other business enterprises can contribute to the promotion, protection and fulfilment of all human rights and fundamental freedoms, in particular economic, social and cultural rights» [4].

Third, the idea of human rights business obligations is opposed by a large proportion of businesses, state and local government representatives. At the same time, the reluctance to impose clear standards and monitor their observance is characteristic not only of corrupt representatives of any government, but also of those who understand that, given the peculiarities of economic activity in the modern world and building relationships across borders, the main burden will be borne by developed countries. 
Analysis of recent researches and publications. Over the last decade, several important studies and publications have emerged, addressing the need to review human rights obligations and to include businesses in the list of obligated entities, standards to be implemented, the legal framework, problems with which all stakeholders face, and existing mechanisms for bringing corporations to justice [See: $2 ; 3,9]$. They continue to promote the lack of proper regulation and enforcement mechanisms at international and national levels for business structures activity.

It is also in line with the trend towards a revision of the human rights concept, the increasing popularity of horizontal human rights and the responsibility of non-state players. It is determined that new phenomenon in strategies to protect human rights is «a shift by global actors concerned about human rights from nearly exclusive attention on the abuses committed by governments to close scrutiny of the activities of business enterprises, in particular multinational corporations» [7, p. 446]. When considering the dangers for human rights and potential business responsibilities of business, the following solutions have been suggested - indirect and direct, where the first corresponds to the indirect withdrawal of business obligations from existing documents and mechanisms, and the second reflects direct and immediate obligations [5, p. 47]. The implementation of such commitments is actively discussed, based on a «due diligence» strategy, as a way of solving problems in the context of globalization and informatization, corporate responsibility and incentives for voluntary compliance [10, p. 860; 6, p. 251-252].

Presenting main material. An adequate regulation in the field of business and human rights remains insufficient, both internationally and nationally. First of all, this is facilitated by the lack of consensus as to whether the business should have direct or indirect, binding or voluntary human rights obligations. On the one hand, voluntary initiatives will be more efficient, but they will not guarantee the protection of rights and no-one would be held responsible in case of refusal to participate in the initiatives. On the other hand, even a human rights protection system built on the obligations of states as direct addressees of rights does not work perfectly. In addition, a voluntary human rights obligations strategy will not provide such coverage and not ensure their execution by companies operating in undemocratic and corrupt states.

It has to be said that business obligations are often focused on certain groups of rights, notably environmental and labor rights, as well as non-discrimination. At the same time, most existing international instruments contain a general statement of the obligation to respect, protect and remedy. UN Global Compact as a standard for business containing ten basic principles, provides that businesses should support and respect the protection of internationally proclaimed human rights; and make sure that they are not complicit in human rights abuses; should uphold the freedom of association and the effective recognition of the right to collective bargaining; the elimination of all forms of forced and compulsory labour; the effective abolition of 
child labour; and the elimination of discrimination in respect of employment and occupation; should support a precautionary approach to environmental challenges; undertake initiatives to promote greater environmental responsibility; and encourage the development and diffusion of environmentally friendly technologies; should work against corruption in all its forms, including extortion and bribery [12]. Questions about the indirect impact on the rights, as well as the degree of liability of the company for complicity in the violations, remain open. For example, the transfer of company production into a state with an authoritarian regime for the sake of cheapening or doing business with a counterparty for which there is evidence of systematic and gross violation of workers' rights.

It should be noted that in any case, public authority does not disassociate itself with the sphere of business and human rights, leaving this sphere to the discretion of companies and civil society. Even a soft obligations option requires the governments use regulation to create an environment more conducive to enterprises voluntarily meeting their social responsibility [6, p. 251].

In discussions that come to a consensus view of the need for a commitment to business obligations and propose the creation of a relevant international document there are differences over which business entities should be covered. Two positions have been formed in this regard: 1. Dissemination of binding standards to transnational corporations only. 2. Dissemination of mandatory standards to all types of companies.

Arguments for assigning obligations to transnational corporations are based on the fact that the latter have economic power, and often also have political weight. This allows them to have a significant impact on human rights, international relations and national legal systems as a whole. The problematic issues of regulating corporations, potentially having consequences for human rights, are the uncertain legal status and understanding of what transnational corporations are. Formally, they belong to the private sector, but acting in the public sector, at the level of governments and international organizations, have the potential to influence regulation and enforcement.

Arguments that a potential convention on human rights for business should also cover national enterprises are based on the necessity of the prevention of human rights abuses, as well as on the understanding that in an information society the influence of a company legally in the jurisdiction of one state can extend far beyond the borders of this state. In addition, specific regulation of business and human rights in national legal systems may be absent or cover only certain narrow spheres. However, as stated above, with the help of certain regulatory schemes, governments «could monitor corporate human rights activity in the same way they monitor corporate environmental, anticompetitive, securities, or bribery-related activity» [7, p. 533-534].

As far as responsibilities of business are concerned, the efforts of many states to apply extra-territorial jurisdiction to matters related to its business should also be taken into account. The clash here is compounded by the fact that information society 
activities are possible in cyberspace, data is transmitted across many countries, and some operations are difficult to trace.

In particular, the EU General Data Protection Regulation, which entered into force on 25 May 2018 for the European Union, imposes rigorous requirements for business on the handling of any data used by companies in their activities, as well as on the observance and protection of individual human rights. Business entities including should be able to demonstrate that they have implemented technical and organizational measures that show how they view and integrate data in processing processes, what they know, what information they own and where they store [8]. The application of this document has already led to several high-profile lawsuits against corporations established in US jurisdiction.

Regulation in the field of business and human rights in Ukraine is based on the above international documents, but today it is fragmented and characterized by the lack of an overall strategy in this matter. As a general guideline, the National Human Rights Strategy, approved by Presidential Decree of August 25, 2015 No. 501/2015, may apply. The National Action Plan on Business and Human Rights, involving all stakeholders, is envisaged to adopted.

Criticism of the ability to implement universal standards for business obligations in the field of human rights, whether imperative or advisory, is also based on a fair fear of not being able to apply them to all business entities, given the variability of companies and differences in their operations, and the fact that managers may not know that businesses are affecting rights in some way [1, p. 338]. Indeed, human rights education is not adapted to such challenges. In addition, even reputable and experienced representatives of international jurisdictions sometimes face complex cases, rather widespread in the sphere of the impact of business on the exercise and protection of rights.

In the information society, resources for business are the attention and trust of consumers of goods and services. Activity in the "gray areas» of law, ethics and technology promises significant profits. Therefore, business interests may be fundamentally at odds with the human rights doctrine. In particular, the key findings of the Ranking Digital Rights for several years now have been to confirm the inadequacy of the disclosure of private data, the non-transparent processing and use of information by companies. In 2017, the ratings of the most popular Internet and mobile companies were as follows: Google (65\%), Microsoft (62\%) and Yahoo! (58\%). In 2018, 17 out of 22 key companies have improved performance in at least one area, but their privacy regimes remain far from ideal [11].

An additional dimension to the problem of rights and company activities is the fact that business structures often operate in the field of the newest human rights, such as prohibition of human cloning, smart bioengineering, maintaining anonymity, digital identity, the right to the Internet, and so on. The concentration of innovative 
technologies in the hands of corporations that are poorly regulated by traditional legal instruments can be quite dangerous.

The human rights recognized as fundamental are also under attack. The global business activities influence information and, in the presence of digital tools and domination of the communication space, significantly affect freedom of expression, pluralism and cultural diversity, democratic processes and the realization of political rights.

At the same time, modern companies may be interested in building a positive image and promoting social responsibility, as well as in maintaining the strong trust of users in the digital age. Certainly, this can have a positive impact on human rights.

Conclusion. In the information society, business has a major impact on human rights that will only grow, taking into account global political, economic and social processes. At the same time, companies can act responsibly or choose the most favorable legal regime for irresponsible activity.

Internationally and at the level of most national legal systems of the world, there are no universal binding standards for the observance and protection of human rights by business. Trends in ongoing regulatory divergences and growing transnational service markets will require further development of legislation and legal practice, global partnerships and innovative approaches.

Further research needs to address the international legal personality of business entities and their direct human rights obligations, the particular responsibility of transnational corporations and the impact of IT companies, the use of autonomous legal regulation and soft law instruments.

\section{REFERENCES}

1. Aaronson, S. A., Higham, I. Re-Righting Business: John Ruggie and the Struggle to Develop International Human Rights Standards for Transnational Firms. Human Rights Quarterly. 2013. Vol. 35, Issue 2. P. 333-364.

2. Baumann-Pauly D., Nolan J. (eds.), Business and Human Rights. From Principles to Practice. Routledge, 2016. 350 p.

3. Corporate Accountability for Human Rights Abuses: A Guide for Victims and NGOs on Recourse Mechanisms, FIDH, 2016 (3rd Edition). 604 p.

4. Globalization and its impact on the full enjoyment of all human rights. Resolution adopted by the General Assembly on 19 December 2016. A/RES/71/197.

5. Knox J. H. Horizontal Human Rights Law. The American Journal of International Law. 2008. Vol. 102. No. 1. P. 1-47. 
6. Ramasastry, A. Corporate Social Responsibility Versus Business and Human Rights: Bridging the Gap Between Responsibility and Accountability. Journal of Human Rights. 2015. Vol. 14. No. 2. P. 237-259.

7. Ratner, S. Corporations and Human Rights: A Theory of Legal Responsibility. Yale Law Journal. 2001. Vol. 111. No. 3. P. 443-545.

8. Regulation (EU) 2016/679 of the European Parliament and of the Council of 27 April 2016 on the protection of natural persons with regard to the processing of personal data and on the free movement of such data, and repealing Directive 95/46/EC (General Data Protection Regulation).

9. Ruggie J. Just Business. Multinational Corporations and Human Rights. Amnesty International Global Ethics Series, W.W.Norton \& Company, New York, 2013. $225 \mathrm{p}$.

10. Shackelford S. J. Human Rights and Cybersecurity Due Diligence: A Comparative Study. University of Michigan Journal of Law Reform. 2017. Vol. 50. No. 4. P. 859-885.

11. The Ranking Digital Rights 2018 Corporate Accountability Index. Available at: https://rankingdigitalrights.org/index2018/ [Accessed 9 August 2019].

12. UNGC. (2015). United Nations Global Compact: The Ten Principles. Available at: https://www.unglobalcompact.org/AboutTheGC/TheTenPrinciples/ index.html [Accessed 1 August 2019]. 